\title{
Views of dairy farmers, agricultural advisors, and lay citizens on the ideal dairy farm
}

\author{
Clarissa S. Cardoso, ${ }^{1,2}$ Marina A. G. von Keyserlingk, ${ }^{2}$ and Maria José Hötzel ${ }^{1 *}$ \\ ${ }^{1}$ Laboratório de Etologia Aplicada e Bem-Estar Animal, Departamento de Zootecnia e Desenvolvimento Rural, \\ Universidade Federal de Santa Catarina, Florianópolis, 88034-001, Brazil \\ ${ }^{2}$ Animal Welfare Program, Faculty of Land and Food Systems, The University of British Columbia, Vancouver, V6T 1Z4, Canada
}

\section{ABSTRACT}

The aim of this qualitative study was to explore the shared and divergent views among Brazilian dairy farmers, agricultural advisors, and lay citizens on what characteristics they viewed were most important on an ideal dairy farm. Responses from 107 dairy farmers, 170 agricultural advisors (including veterinarians), and 280 lay citizens were subjected to thematic analyses. Five themes were identified: milk quality, animal welfare, economics, society, and the environment. Although all 3 groups made reference to each of the 5 themes, they emphasized different characteristics. The lay citizens placed the most emphasis on milk quality. In contrast, both the farmers and the advisors highlighted economics as the most important characteristic of an ideal dairy farm. When considering only animal welfare, we noted differences in the use of the constructs of animal welfare: farmers and advisors referred mostly to aspects related to biological functioning, whereas lay citizens emphasized affective states and naturalness. All 3 stakeholder groups referred to the use of pasture as being an important component of an ideal dairy farm but again differed in their reasons; citizens referred to pasture in the context of naturalness, whereas the other 2 stakeholder groups almost always referred to pasture using economic terms. Technology was highlighted by all 3 groups as an important characteristic of an ideal dairy farm but differences were noted in their justification for this view. For example, lay citizens viewed technology as a tool to improve milk quality, whereas farmers and advisors both referred to technology as an important vehicle to improve quality of life for those working in the industry. Lay citizens raised several concerns associated with the overuse of antibiotics and other chemicals, but farmers and advisors rarely mentioned these types of concerns. The latter 2 stakehold-

Received March 4, 2018.

Accepted October 7, 2018.

*Corresponding author: maria.j.hotzel@ufsc.br ers placed considerable emphasis on the quality of life of dairy farmers and workers, an issue rarely discussed by lay citizens. Overall, our findings highlight several disconnects between the expectations of the lay citizens, and farmers and their advisors. We suggest that dairy farmers and agricultural advisors should both reflect on the desires of the lay public in what they view to be an ideal dairy farm, as this may help bridge some of the current disconnects.

Key words: Brazil, survey, animal welfare, milk production

\section{INTRODUCTION}

Differences in concerns and opinions about similar issues on the topic of food animal production practices exist between different stakeholders, likely driven by diverging self-interests and values (Te Velde et al., 2002; Dockès and Kling-Eveillard, 2006; Vanhonacker et al., 2008; van Asselt et al., 2018). Several studies have investigated the views and opinions of lay citizens (people who self-identified as having no involvement in animal production) on the topic. For example, lay citizens frequently associate high standards of animal welfare with higher quality animal products and reject the use of chemicals, including antibiotics and hormones, for purposes of increasing production (Barlow, 2011; Boogaard et al., 2011; Clark et al., 2016; Pieper et al., 2016). Also, considerable evidence indicates that lay citizens expect farm animals to be well treated and to live a more natural life (Lassen et al., 2006; Prickett et al., 2010). Some accounts indicate that at least some lay citizens perceive farm animals to be living in conditions that are far from optimal (Te Velde et al., 2002; Clark et al., 2016).

European (Eurobarometer, 2007) and US (Wolf et al., 2016) lay citizens believe that farmers have the most influence on the welfare of dairy cattle. Farmers have complex views about issues related to animal welfare. For example, they are concerned with production but also recognize animals as sentient beings (Dockès and 
Kling-Eveillard, 2006; Wikman et al., 2013; Cardoso et al., 2016b). Furthermore, decision-making regarding farm animal management seems to be influenced by several factors such as economic, ethical, and emotional attachment regarding animals (Driessen, 2012), as well farmers' understanding regarding their animals (Dockès and Kling-Eveillard, 2006). Several studies have shown that individuals involved with animal production express less concern over animal welfare than do lay citizens (Te Velde et al., 2002; Lassen et al., 2006; Vanhonacker et al., 2008). For example, in the study of Vanhonacker et al. (2008), compared with lay citizens, farmers express less concern about some aspects of animal welfare, such as the ability to engage in natural behaviors, aspects related to pain or stress, and the availability of space.

Others who potentially affect the management of dairy farms are their advisors, such as agriculture extension agents, nutrition consultants, herd veterinarians, animal scientists, and hoof trimmers, who may or may not have a direct financial interest in the farm. Given their important advisory role, it is surprising that only a few studies have summarized the views of this important stakeholder group (e.g., reviewed by Cornish et al., 2016; Sumner et al., 2018). The limited work to date indicates that agricultural extension agents prioritize animal health and production over other aspects of animal welfare (Cantrell et al., 2013; Hötzel and Sneddon, 2013).

Encouraging engagement among different stakeholders to identify similarities (and differences) in views and opinions is a viable vehicle to identify sustainable practices in animal production (Driessen, 2012; Hötzel, 2016). Considering the scarcity of knowledge regarding the attitudes of farmers and stakeholders who work directly with the dairy industry, and whether they are in agreement (or not) with lay citizens in Brazil (Cardoso et al., 2017; Rucinque et al., 2017; Vargas-Bello-Pérez et al., 2017; Yunes et al., 2017), we set out to investigate the views of these 3 different stakeholders. The aim of this study was to explore the shared and divergent views among Brazilian dairy farmers, agricultural advisors, and lay citizens on what characteristics they viewed were most important on an ideal dairy farm, and their associated reasons.

\section{MATERIALS AND METHODS}

This study was exploratory in nature and was based on a qualitative approach, which is ideal to generate data to interpret and understand point of views of people (Denzin and Lincoln, 2005, page 3; Guest et al., 2012, page 6). In qualitative research, it is assumed that a convenience sample provides a rich and diverse set of responses when saturation (i.e., when the responses become repetitive) on the proposed topic is achieved (Robson and McCartan, 2016, pages 166-167 and 281). To understand the views of Brazilians involved and not involved in animal production, we surveyed (1) dairy farmers, (2) agricultural advisors, and (3) lay citizens. Survey participants were 18 years or older, participated voluntarily and remained anonymous. Each participant received a consent form that they were asked to read and, if they agreed to participate, were required to sign before they began the survey. The research protocols used herein were approved by the Ethics Committee of Research with Human Beings of Federal University of Santa Catarina, Brazil (1539053 and 1248867).

We invited participants to respond to a single openended question that had previously been used by Cardoso et al. (2016a): How do you imagine an ideal dairy farm and why are these characteristics important to you? This was followed by multiple-choice demographic questions (age, sex, education, area of residence, and involvement in animal production). Our intention was to reach a diverse group of respondents, so we recruited participants through different channels.

\section{Recruitment of Dairy Farmers and Agricultural Advisors}

Given their close working relationship, dairy farmers and agricultural advisors were recruited using the same vehicles. Some participants within these 2 groups ( $\mathrm{n}=112)$ were recruited through 2 dairy production portals that have national coverage: Milk Point (https: //www.milkpoint.com.br/) and Revista Leite Integral (http://www.revistaleiteintegral.com.br/); both of these websites were linked to the online questionnaire via their Facebook pages. Some participants $(\mathrm{n}=148)$ were recruited via social media by the first author, who sent the online questionnaire invitation (link) via social media, such as Facebook and WhatsApp, and to email groups with interests in veterinary, agronomy, or animal science. Finally, an additional 17 dairy farmers were recruited at a dairy cattle conference held in the city of Castro, Brazil. All participants included as farmers $(\mathrm{n}=107)$ or advisors $(\mathrm{n}=170)$ had self-identified as having some involvement in animal production. Participants that self-identified as being both farmer and advisor $(\mathrm{n}=46)$ were considered farmers.

\section{Recruitment of Lay Citizens}

Lay citizens $(\mathrm{n}=280)$ were recruited at the Hercílio Luz International Airport (Florianópolis, Brazil). 
The airport location was chosen because of the intense movement of middle-class people (ANAC, 2014) of both sexes and different ages. People in the airport hall who were waiting for flights or for arriving passengers were approached and invited to participate in the study by asking if they were interested in voluntarily answering a short questionnaire covering the general theme of "animal production." All interviews were done in Portuguese; the responses were transcribed into a digital document.

\section{Thematic Analyses}

The responses of the 3 groups of stakeholders were analyzed separately. We used the NVivo Qualitative Data Management Program (version 11, 2015; QSR International Pty Ltd., Doncaster, VIC, Australia) to organize the data and code the answers. Characteristics and reasons given for what constitutes an ideal dairy farm were analyzed together to contextualize the presented characteristics. We performed a thematic analysis, the most commonly used method in qualitative research, as it is useful to capture complexities of meanings in text data (Guest et al., 2012, page 3). This method consists of describing ideas arising from the transcriptions that arose through the data collection period and identifying themes using a codifying process. It involves careful reading and rereading of the transcriptions and identification of key words, phrases, trends, and themes (Guest et al., 2012, pages 6 and 9). The specific steps for this type of analysis are data reduction (information is coded to find themes); data display (organization of the information allowing conclusions to be drawn); and conclusion drawing and verification (noting of patterns and themes and using confirmatory tactics such as triangulation between 3 readers; Miles and Huberman, 1994, pages 10-12). The first author (CSC) plus 2 trained researchers independently examined 30 randomly selected responses from each stakeholder group with the aim of improving reliability in the analysis before the remaining responses were analyzed. The individual responses were broken down into phrases, which were then codified into themes. The 3 readers compared results and reconciled any discrepancies, and the first author (CSC) then undertook the remaining analyses. Many responses bridged more than one theme and were thus coded into multiple themes. Quotes that were representative of specific themes that appear in the paper were translated to English by the first and last authors. Quotes have been modified for length and clarity: ellipses indicate where text was omitted to reduce quote length, and brackets indicate the authors' additions to the text.

\section{RESULTS}

The demographic profile of each group of participants is presented in Table 1. The majority of dairy farmers who participated in our study lived in rural areas, whereas the majority of participating agricultural

Table 1. Participants' demographics (values in percentages)

\begin{tabular}{|c|c|c|c|c|}
\hline Demographics & Variable & $\begin{array}{l}\text { Farmers } \\
(\mathrm{n}=107)\end{array}$ & $\begin{array}{c}\text { Advisors } \\
(\mathrm{n}=170)\end{array}$ & $\begin{array}{l}\text { Lay citizens } \\
(\mathrm{n}=280)\end{array}$ \\
\hline Age, yr & $\begin{array}{l}18-24 \\
25-34 \\
35-44 \\
\geq 45\end{array}$ & $\begin{array}{r}7 \\
33 \\
28 \\
32\end{array}$ & $\begin{array}{l}14 \\
37 \\
25 \\
25\end{array}$ & $\begin{array}{l}16 \\
24 \\
25 \\
35\end{array}$ \\
\hline Sex & $\begin{array}{l}\text { Male } \\
\text { Female }\end{array}$ & $\begin{array}{l}85 \\
15\end{array}$ & $\begin{array}{l}60 \\
40\end{array}$ & $\begin{array}{l}48 \\
52\end{array}$ \\
\hline Education & $\begin{array}{l}\text { Elementary school } \\
\text { Technical degree } \\
\text { Bachelor's degree } \\
\text { Graduate degree }\end{array}$ & $\begin{array}{r}17 \\
9 \\
47 \\
27\end{array}$ & $\begin{array}{r}2 \\
7 \\
39 \\
52\end{array}$ & $\begin{array}{r}18 \\
9 \\
45 \\
28\end{array}$ \\
\hline Area of residence & $\begin{array}{l}\text { Rural } \\
\text { Urban }\end{array}$ & $\begin{array}{l}67 \\
33\end{array}$ & $\begin{array}{l}31 \\
69\end{array}$ & $\begin{array}{l}12 \\
88\end{array}$ \\
\hline
\end{tabular}


advisors and lay citizens lived in urban areas. Most participants in all 3 groups were highly educated, with at least a bachelor's degree.

We identified 5 common themes in the responses of all stakeholders: milk quality, animal welfare, economics, societal issues, and environmental issues (Figure 1).

\section{Aspirations of Farmers and Advisors Regarding the Ideal Dairy Farm}

Because the identified themes in farmers and advisors responses were generally similar, we described the results of these 2 stakeholders together in this section. Whenever a specific theme was identified in only one group, we noted this in the text.

Economics. The main characteristic of an ideal dairy farm, according to farmers and advisors, were related to factors that they perceived as affecting profitability, such as production, productivity (Figure $2 \mathrm{~A}$ and $2 \mathrm{~B}$ ) and "economic viability" (Farmer 12); for example, "[A farm with] good profitability, good productivity, lots of efficiency" (Farmer 31); "[An ideal dairy farm is one where] increases in productivity lead to more profit to farmers" (Advisor 15). Farmers producing all the necessary resources needed on the farm was often mentioned, "[A farm] should be self-sustaining, and produce manure, pasture, cereals, electricity (...)" (Farmer 38); "Ideally a self-sustaining system, that is, one that produces absolutely no impact and can rely exclusively on resources generated by the farm" (Advisor 24). Efficiency was used in terms of use of resources: "[A farm that has] high efficiency in the use of available resources, like land, water, labor, etc." (Farmer 3); "I imagine an ideal farm producing milk at low costs, which means pasture based, but with technology, to be an efficient system" (Farmer 93).

Farmers and advisors cited elements that, in their understanding, increase productivity, such as genetics, reproduction, feeding (nutrition), farm management, good workers, facility cleanliness, and type of housing.

Milk Quality. Milk quality was mentioned as a key characteristic of an ideal dairy farm; for example, "To me the ideal dairy farm should primarily be dedicated to produce high quality milk ..." (Farmer 10); "[An ideal dairy farm is one that] produces high quality milk for human consumption" (Advisor 12). Four advisors referenced the use of chemicals by farmers; for example: "Agroecological production because it does not contaminate the milk with insecticides and other chemicals" (Advisor 80); "... without hormones, just homeopathy (or antibiotics in case an animal's life is on risk, for example)" (Advisor 115).

Animal Welfare. Farmers and advisors also cited the term "animal welfare"; for example, "Milk quality and animal welfare should be priorities ..." (Farmer 85). The term was often associated with facilities and management: "[The farm] needs to provide welfare to the animals, but not just the climate comfort aspect that significantly affects production, also with rational management, without any violence with the cows." (Farmer 41); "... animal welfare, in terms of facilities as well as management ..." (Advisor 46). Animal comfort was related to animal housing and productivity, "Ian ideal dairy farm $]$... respects housing conditions and comfort to the animals" (Advisor 136); "Where the animal has maximum comfort to produce its maximum ..." (Farmer 106). Only a few demonstrated concern about the affective states of animals; for example, "An adequate

\section{$\square$ Farmers $\square$ Advisors $\square$ Lay citizens}

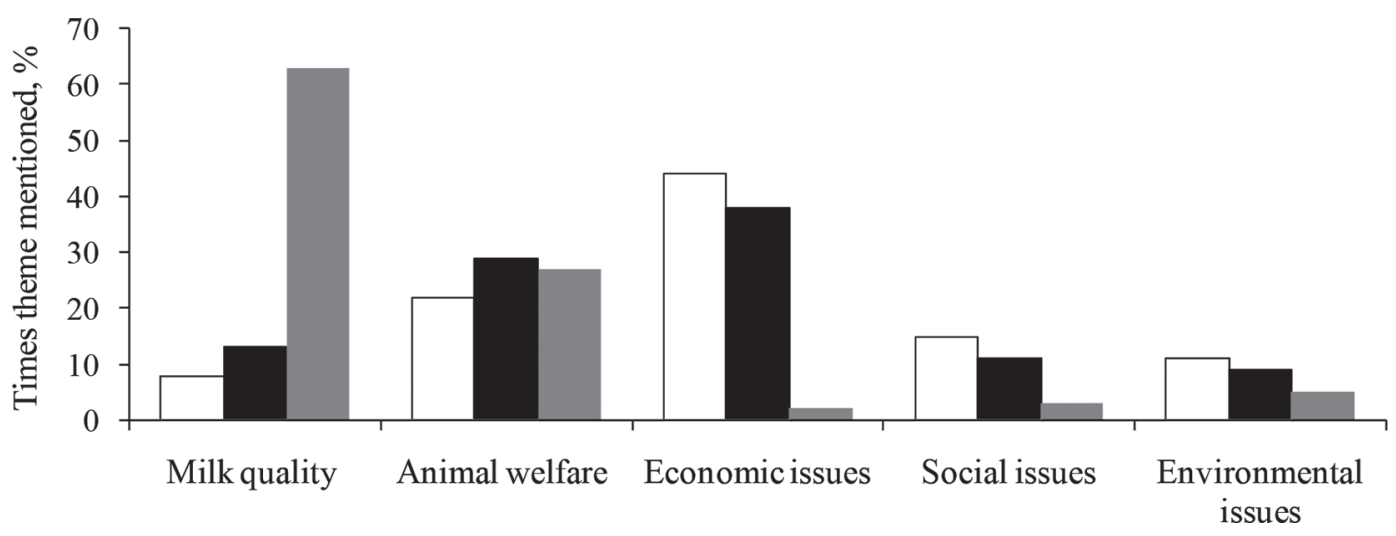

Figure 1. The percentage of times a particular theme was mentioned by dairy farmers $(\mathrm{n}=107$, white bars), dairy advisors $(\mathrm{n}=170$, black bars), or lay citizens $(n=280$, gray bars) in response to being asked a single open-ended question: What do you consider to be an ideal dairy farm and why are these characteristics important to you? 
environment for the animals and for the workers. It does not matter if it is pasture or confinement, the cow should have high quality food, water, a place with shade to rest, good milking management and, when necessary, fast and efficient interventions to avoid animal suffering" (Farmer 126); "Where animals are respected, not just used ..." (Advisor 61).

Environment. Some participants of these groups showed awareness that animal welfare and environmental concerns are characteristics demanded by the lay citizens; for example, "An ideal dairy farm should have specialized workers and management based on animal welfare (...) I believe that this is a great basis for dairy production because it will meet, in the future, the expectations of consumers, besides being ethically coherent with the modern concepts of animal production." (Advisor 3). Environmental issues were discussed broadly in terms of the farm practices adhering to legislation, avoiding harm and preserving the environment, ". . . ecologically correct. With the best possible use of energy and natural resources" (Farmer 54).

Pasture-based systems were cited by both advisors and farmers, who listed a range of benefits in terms of production, profitability, animal welfare and environmental sustainability: "Shade, water and pasture during the day and night. This is the only way the animals can be free to express their natural behavior" (Farmer 127); "I imagine an ideal farm producing milk with low costs of production, which means, pasture based ..." (Farmer 93); "... an ideal dairy farm has pasture based production, because it has less workload ..." (Farmer 92); "Pasture based milk production because I believe that this model could generate the best result for the farmer"
(Advisor 121); "Pasture based - it is important to ensure environmental sustainability, soil fertility, quality of pasture and year-round production" (Advisor 57).

Social Concerns. Farmers and advisors placed great emphasis on the quality of life of farmers and workers. They cited characteristics such as the wellbeing of people, quality of life, comfort, happiness, social responsibility, dignity, and the need for rest on weekends and vacations; for example, "The family or people involved on that work must have vacations and guarantee for salary so they can they live well, with health insurance, good housing and leisure" (Farmer 96); "[A dairy farm that] can warrant dignified conditions and less workload for the workers" (Advisor 73). Also, advisors expressed a specific concern about rural succession; for example, "An essential issue is to support youth, they will ensure continuity of the work; they should be supported to continue in the business and ensured that is life quality in the countryside" (Advisor 48). Some justified profitability as a desired feature due to social concerns; "[With] profitability the producer can invest in the activity and provide higher quality of life for himself and his family" (Farmer 36); "Good productivity and profit to provide comfort and quality of life" (Advisor 10). One advisor commented about sex differences in leadership roles on dairy farms, "I would like that women had power of decision in this activity [dairy] and not just the "family men"' (Advisor 63).

Technology was discussed as an important tool to reduce workloads and ease management, and participants often mentioned it in reference to employees or family workers: "Farm routines with as much automation as possible throughout the entire production process will
A) Farmers

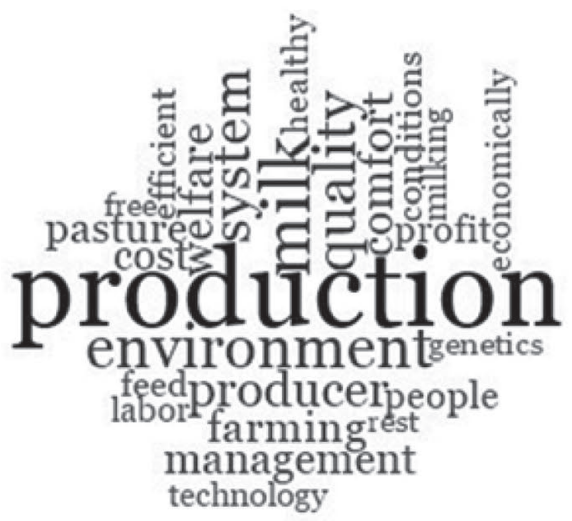

B) Advisors

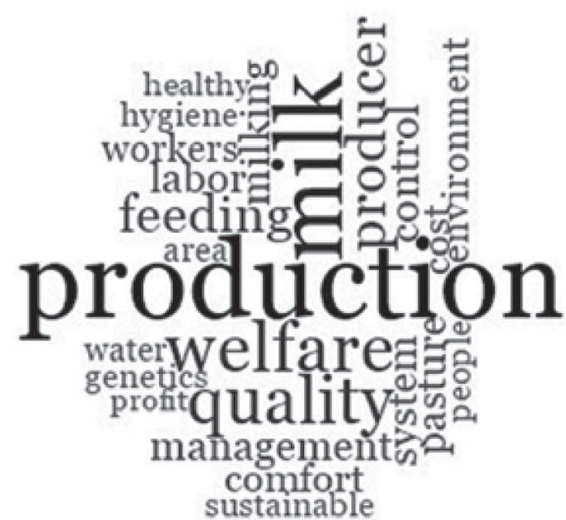

C) Lay citizens

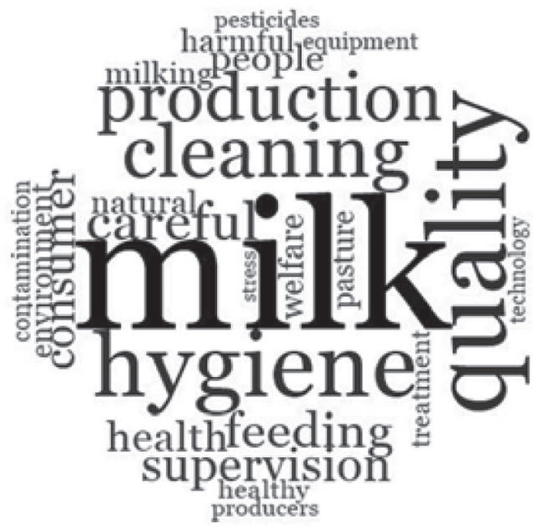

Figure 2. Word clouds generated using the 25 most frequent words generated by each of the stakeholders in response to the question "What do you consider to be an ideal dairy farm and why are these characteristics important to you?" Words appearing in larger, bolder type were used most frequently. The word clouds were originally made in Portuguese and then translated into English. 
improve work efficiency, thus allowing time for the small producers to rest" (Farmer 32); "Tools, technologies and equipment better adjusted to the economic reality of rural properties, to reduce excessive workload, often hard work, and to improve the quality of life of the producer" (Advisor 33).

\section{Aspirations of Lay Citizens Regarding the Ideal Dairy Farm}

Lay citizens focused their comments mainly on milk quality and concern for the animals (Figure 2C); for example, "The ideal would be one [farm] concerned with milk quality and with the animals" (Citizen 108), and frequently linking both: "A farm that allows good animal welfare (...) because I believe that milk quality has a direct association with animal welfare" (Citizen 63).

Milk Quality. More than half of the lay citizens cited milk quality, many of them justifying it as important for people's health; for example, "[A farm] ... that produces milk with good quality for my health" (Citizen 213). Additionally, overall hygiene and cleanliness of facilities, stockpeople, cows, and tools or instruments used during milking were relayed, particularly in relation to cleanliness being important for milk quality; for example, "[An ideal dairy farm] should take care with hygiene to not contaminate the milk" (Citizen 2). Assurance of high milk quality also came with an expectation that the farm was automated and that workers were well trained in how to maintain food safety; for example, "I believe that the farm would have to be all automated to avoid risks of contamination" (Citizen 211), and that there was oversight providing assurance on this issue; for example, "[A farm] with better supervision of milk quality and hygiene" (Citizen 57). Participants commented that the ideal dairy farm should be organic: "[A farm] with fully organic inputs and oversight is important given the current reality of milk adulteration, and mainly to ensure healthier products" (Citizen 256). Abstaining from using chemicals in dairy production was also mentioned by lay citizens; milk should be produced using less or no hormones, antibiotics, preservatives, pesticides on the pasture, or other additives or chemical products; for example, "[A farm] without hormones; other medicines like antibiotics should only be used if there is a bacterial infection; pesticides should be avoided and just used if there are no other treatment options" (Citizen 200). These factors were important for milk quality and food safety; for example, "It is important that high quality milk be produced, without pesticides and other elements that are found illegally in the milk today" (Citizen 25).

Lay citizens who answered our question also made mention of terms or phrases associating the ideal dairy farm with naturalness of the production system; for example, "... I believe the more natural, the better the final product" (Citizen 180); "... ideally, natural animal production should be maintained, without any ways that force it and impair its essence" (Citizen 142); "Less stressful and anti-natural management as possible" (Citizen 197); “... dairy cattle reared in their natural environment because to me it is important to know that the milk that I consume has a good origin" (Citizen 216).

Providing cows with natural feed in the voice of the lay citizens was often coupled with the word "pasture." For instance, cows' should be able to feed naturally; for example, "[An ideal dairy farm is one that has] adequate pasture and feeding, as natural as possible" (Citizen 78). The preference for pasture was also coupled with providing a better life for the cows: "Where the cows stay untied, on pasture, able to feed and walk naturally. Because I think that freedom should not be denied to any animal" (Citizen 54); "[A farm with] extensive rearing, natural pasture, so that animals are not stressed" (Citizen 115).

Animal Welfare. Lay citizens were concerned about the quality of treatment given to animals: "Is important to me because I want pure milk for consumption, without animal mistreatment" (Citizen 91); "... Animals without stress or trauma; because the animals' welfare comes first, before human needs" (Citizen 93). For lay citizens, animals should be treated with respect, care, and affection; for example, "I would expect respect for the animals" (Citizen 161); "... special care and affection for animals" (Citizen 56). Participants also spoke about animals having a good life and being able to live in a comfortable environment, with enough space, without machines, with their calves, and with freedom: "I believe that an ideal farm should have enough space for the animals to have some life quality" (Citizen 11); "I imagine a big farm where the animals can graze and walk, not where they are confined, and where they are taken (by someone that likes animals) for milking by hand or by machines and equipment that doesn't hurt them" (Citizen 166); "I've seen media reports and it scares me the amount of machinery that is used. It should be something more humane for the cows" (Citizen 34); " $[A$ farm with] animals free on pasture, confined just for a brief period, calves with their mothers as long as possible. Animals have feelings just like us and therefore I believe it is important that they live as happy and healthy as possible" (Citizen 130).

Environment For a few lay citizens, the ideal dairy farm was one that had practices that were environmentally friendly. Phrases such as "concern," "respect" and "protection of the environment" were used: "... the environment is essential for our future and of other beings" (Citizen 223) and "A farm that is innovative and is pay- 
ing attention to preserving the environment in a sustainable way" (Citizen 17). In essence, many of the citizens wanted it all: "An ideal dairy farm should be concerned not just with the final product that is marketed, but also with the welfare of the animals, the environment, and the producer" (Citizen 162).

\section{DISCUSSION}

Although all 3 stakeholder groups cited milk quality, animal welfare, economics, and societal and environmental issues as important, they placed different emphasis on each of the themes. Whereas lay citizens highlighted milk quality, both farmers and advisors spoke mostly about economics. When considering only animal welfare, we also noted differences in the use of different constructs of animal welfare: biological functioning - emphasizing health, growth, nutrition; affective states - referring to the animal's feelings such as pain and pleasure; and naturalness - referring to the animals' ability to perform their natural behaviors (Fraser et al., 1997). The farmers and advisors primarily referred to aspects related to biological functioning and health, whereas the lay citizens primarily emphasized affective states and naturalness.

When asked their views on what constitutes an ideal dairy farm, the responses from the farmers and advisors were very similar, and different from those of the lay citizens. van Asselt et al. (2018), who surveyed Dutch citizens, poultry farmers, and poultry veterinarians about health and food safety comparing indoor and outdoor systems, reached the same conclusion. Differences in perceptions between farmers and citizens have been reported previously (e.g., Te Velde et al., 2002; Benard and de Cock Buning, 2013). All 3 groups made reference to animal welfare but placed different emphasis on the 3 constructs - biological functioning, affective states, and animals' ability to live a natural life (Fraser et al., 1997). The lay citizens who responded to our questions were most concerned with the quality of treatment given to the animals but also to aspects that fell within the animal welfare concept of "naturalness." This is in line with previous reports indicating that citizens are primarily concerned with farming practices that they perceive to influence affective states of the farm animals (Vanhonacker et al., 2008), the way animals are treated (Te Velde et al., 2002), and with naturalness (Lassen et al., 2006; Prickett et al., 2010). Although the developing countries have been slower to document these types of concerns (von Keyserlingk and Hötzel, 2015; Vargas-Bello-Pérez et al., 2017), recent studies (Cardoso et al., 2017; Rucinque et al., 2017; Yunes et al., 2017) suggest that animal welfare is becoming an increasingly important topic in Brazil.
Most farmers and advisors participating in our study limited their discussion to issues related to the biological functioning construct of animal welfare, frequently referring to basic health and good facilities, without any explanation of why these characteristics would be important for the farm; only a few farmers and advisors demonstrated concern about the affective states of the animals. Others have also reported that farmers and extension agents place greater emphasis on biological functioning (i.e., Te Velde et al., 2002; Vanhonacker et al., 2008; Cantrell et al., 2013). Also, agricultural advisors play an important technical support role in aiding farmers' activities, which places them in a potentially influential position to help guide the industry. Meijboom (2017) argues that veterinarians working on food production must be independent from the concerns and interests of other stakeholders (e.g., farmers and lay citizens) to deal with ethical challenges such as animal welfare. Professionals should be able to deal with different and divergent values of those stakeholders and advise governments to make regulations (see more in Meijboom, 2017). Interestingly, in this study, it is clear that advisors portray very similar views to those of their primary clients - the farmer.

Although milk quality was the primary concern raised by lay citizens, farmers and advisors rarely mentioned it. When referring to milk quality, the lay citizens also clearly articulated that to achieve high standards of milk quality, other features such as hygiene, cleanliness, animal welfare, animal health, legislation, and trained workers were important. Again, farmers and advisors failed to link these characteristics with milk quality, and only a few farmers linked them with productivity. Growing public demand for healthy food (Arvola et al., 2008; Dean et al., 2012; O'Brien et al., 2015; Guivant and Macnaghten, 2015) and global concerns for farm animal welfare have received much attention (see also Clark et al., 2016). Lay citizens' emphasis on milk quality and the need for strict sanitary conditions and government regulations may reflect in part the reporting of milk adulteration scandals that have occurred in Brazil in recent years (Folha, 2007; Debona, 2014; Lehmen, 2017), a topic that was specifically referred to by some of our lay citizens. That the farmers and advisors failed to show similar concerns may be explained to some degree by the milk adulteration events being viewed as issues beyond the physical boundaries of the farm. It is also concerning that milk quality measures taken on a large proportion of farms in Brazil are below government quality standards (Oliveira et al., 2011; Balcão et al., 2017).

Naturalness, cited by lay citizens as an important characteristic of dairy farming, is a highly praised topic by the lay public around the world (Lassen et al., 2006; 
Prickett et al., 2010). Normally citizens associate a preference for access to pasture for cattle with naturalness (Boogaard et al., 2008; Ellis et al., 2009; Miele et al., 2011; Hötzel et al., 2017). Most interesting in our study was that all 3 stakeholders considered pasturebased systems to be the ideal rearing system for dairy cattle but they differed in why they viewed it to be important. Lay citizens cited naturalness, whereas both advisors and farmers emphasized potential benefits for milk production, the animals, the farmers, and the workers. This support for pasture by all stakeholders is promising for this type of system, considering that more than $80 \%$ of cattle production in Brazil currently takes place on pasture (IBGE, 2009).

Lay citizens who participated in our study rejected the use of antibiotics, hormones, and pesticides, an issue considered important by lay citizens in other studies (Clark et al., 2016; Pieper et al., 2016; Hötzel et al., 2017). Consumers' rejection of antibiotics and hormones is often associated with preference for naturalness of the system and product quality (Clark et al., 2016). Although farmers and advisors demonstrated that they are paying attention to public and market demands, by recognizing that animal welfare and product quality are important on an ideal dairy farm, they rarely referenced the use of antibiotics and hormones. The fact that only 4 advisors commented on the use of antibiotics is worrisome and we encourage future quantitative studies that make use of representative samples to determine whether this is indeed a valid concern. Advisors are in a unique position to contribute to this effort; according to Magouras et al. (2017), understanding their attitudes on this topic is a major step toward reducing antibiotic resistance. Clearly, different stakeholders assess the use of antibiotics and hormones as tools for animal production from different perspectives and with a different knowledge base (Barlow, 2011; Pieper et al., 2016). In view of the growing international interest in this issue, it is likely that changes will be required; thus, attitudes of farmers and their advisors should be explored to prevent them from being barriers for change.

Although lay citizens associated modern farm equipment and technologies with high milk quality, farmers and industry specialists associated these technologies with social issues, particularly from a worker perspective. Specifically, they commented on the fact that technology can decrease the workload placed upon farm workers, which they argue improves the quality of life of both farmers and workers. The debate regarding modernity in agriculture (Fraser, 2008; Boogaard et al., 2011; Thompson, 2012) is worthy of further discussion. According to Boogaard et al. (2011), society shows ambivalence toward modernity in farming systems, criticizing the loss of naturalness, traditions, and values in food production and the perceived negative effects on nature and animals (while appreciating the improvements in food quality and food safety). Thompson (2012) argues that different people have different points of view about agriculture, ranging from an industrial view to an agrarian view. In our study, lay citizens took on a more agrarian view when citing characteristics related to naturalness and concern regarding animals, but not exclusively, as they also took on an industrial view when noting that the implementation of technology ensures milk quality. Not surprisingly, farmers and advisors praised characteristics of a dairy farm that reflected an industrial view of agriculture, using words such as efficiency, profit, and technology. However, their associated reasons clearly reflected their interests in reducing workloads and ensuring a better quality of life for rural people living and working on farms, aspects that arguably also reflect an agrarian view of agriculture.

The farmers and advisors showed considerable concern for the quality of life of the people who are directly involved in the daily running of the dairy farm. Some of them discussed family succession, likely reflecting their concerns about securing a future for agriculture (in this case, dairy production). Productive, economic, and social conditions determine the willingness of the next generation to stay at the farm (Spanevello, 2008). Internal family conflicts and the hard work-which includes working on weekends and holidays but does not result in extra income - act as deterrents for the young, preventing them from remaining on the family farm (Stropasolas, 2011). The creation of a special policy referred to as the National Plan of Youth and Rural Succession (MDA, 2015) shows the dimension and contemporaneity of this issue in Brazil. Succession within family farming is particularly important in the dairy industry, given that family farms produce $60 \%$ of the milk in Brazil (IBGE, 2009).

All 3 groups of stakeholders commented that the ideal dairy farm should take into account aspects related to the environment. The debate regarding the negative environmental impacts of livestock production is complex, with no clear and easy solution. For instance, some solutions could result in social problems, such as loss of livelihood for people that depend on livestock (Steinfeld, 2006) but resonate with consumers and environmental advocates. Considering the complexity of these issues (Van Calker et al., 2005), it follows that solutions must consider all 3 aspects for sustainability (i.e., economic, social, and ecological).

We surveyed 3 separate groups of people with the aim of identifying topics that were of interest to them 
when asked about an ideal dairy farm and their underlying reasons. This type of work does not make statistical inferences regarding differences among these groups but does play a key role in generating data for other researchers to help guide future investigations (Guest et al., 2012). In this way, we suggest that complementary studies could include investigating the views of specific types of farmers and their associated stakeholders (corporate agriculture businesses or small family farmers, organic producers, and so on) but also quantitative approaches using representative samples or qualitative methodologies that allow different stakeholders to present and discuss their views. In general, the age and sex of lay citizens were well distributed according to the latest Brazilian census (IBGE, 2012). In contrast, the majority of farmers and advisors were male. The high proportion of male farmers is in accordance with the last Brazilian agricultural census that reported that $87 \%$ of people primarily responsible for the farm unit are men (IBGE, 2009); the groups of advisors (40\% women) and lay citizens ( $52 \%$ women) were more balanced by sex. Just one participant, from the advisor group, mentioned the issue of sex of participants in dairy farming, a factor that is known to influence the attitudes of people, especially regarding animal welfare. Clark et al. (2016), in their review of 80 studies, indicated that women generally are more concerned about animal welfare than men and will have more negative attitudes toward modern farming. In Brazil, particularly in family farms, women have long played an important role in dairy production (Magalhães, 2009). Readers should therefore consider this aspect of sex when interpreting our results. We also encourage future work on the issue of sex, particularly among family-run dairy farms and the potential role that this factor may play when advocating for change.

\section{CONCLUSIONS}

Our findings showed that aspirations regarding an ideal farm of dairy farmers and agricultural advisors were very similar, with both groups placing great emphasis on economics. In contrast, the lay citizens reported milk quality to be their primary concern, an issue rarely mentioned by the other 2 stakeholders, but also referenced aspects that fell under the concept of naturalness. All stakeholder groups mentioned animal welfare as a key concern but they differed in the emphasis placed on the different constructs of animal welfare. Overall, our findings highlight several disconnects between the expectations of the lay public and those of dairy farmers and agricultural advisors. We suggest that dairy farmers and agricultural advisors should consider reflecting on the desires of the lay public in what they view to be an ideal dairy farm, as this may help bridge some current disconnects between those working within the dairy industry and those who buy dairy products.

\section{ACKNOWLEDGMENTS}

We are grateful to Milk Point and Revista Leite Integral for publishing our survey on their websites and through social media, as well as the Brazilian Airport Infrastructure Company (INFRAERO) for allowing us to administer the survey in the airport of Florianópolis. We also thank Daniel Weary (University of British Columbia) for collaboration in developing the "ideal dairy farm" concept. This research was funded by $\mathrm{CNPq}$ (National Council for Scientific and Technological Development, Brazil) through Grant No. 404403/2016-6 and the Science Without Borders program (Grant No. 400850 2013-3), which also provided funding to M. A. G. von Keyserlingk to facilitate her stay in Brazil. C. S. Cardoso was awarded scholarships from the Government of Canada Emerging Leaders in the Americas Program (ELAP) scholarship, which provided funds to support her visit to the Animal Welfare Program, University of British Columbia, and from the Foundation for Research and Innovation of the State of Santa Catarina (FAPESC). M. J. Hötzel received support from CNPq, through Grant No. 311509/2015-0.

\section{REFERENCES}

ANAC. 2014. O Brasil Que Voa. Accessed Nov. 15, 2017. http://www .aviacao.gov.br/obrasilquevoa/.

Arvola, A., M. Vassallo, M. Dean, P. Lampila, A. Saba, L. Lähteenmäki, and R. Shepherd. 2008. Predicting intentions to purchase organic food: The role of affective and moral attitudes in the Theory of Planned Behaviour. Appetite 50:443-454. https://doi.org/10 .1016/j.appet.2007.09.010.

Balcão, L. F., C. Longo, J. H. C. Costa, C. Uller-Gómez, L. C. P. M. Filho, and M. J. Hötzel. 2017. Characterisation of smallholding dairy farms in southern Brazil. Anim. Prod. Sci. 57:735-745. https: //doi.org/10.1071/AN15133.

Barlow, J. 2011. Antimicrobial resistance and the use of antibiotics in the dairy industry: Facing consumer perceptions and producer realities. Pages 47-58 in Western Canadian Dairy Seminar Proceedings 29th Western Canadian Dairy Seminar, Red Deer, Alberta, Canada.

Benard, M., and T. de Cock Buning. 2013. Exploring the potential of Dutch pig farmers and urban-citizens to learn through frame reflection. J. Agric. Environ. Ethics 26:1015-1036. https://doi.org/ 10.1007/s10806-013-9438-y.

Boogaard, B. K., B. B. Bock, S. J. Oosting, J. S. C. Wiskerke, and A. J. van der Zijpp. 2011. Social acceptance of dairy farming: The ambivalence between the two faces of modernity. J. Agric. Environ. Ethics 24:259-282. https://doi.org/10.1007/s10806-010 -9256-4.

Boogaard, B. K., S. J. Oosting, and B. B. Bock. 2008. Defining sustainability as a socio-cultural concept: Citizen panels visiting dairy farms in the Netherlands. Livest. Sci. 117:24-33. https://doi.org/ 10.1016/j.livsci.2007.11.004. 
Cantrell, R., B. Lubben, and D. Reese. 2013. Perceptions of food animal welfare in extension: Results of a two-state survey. J. Ext. $51: 10$

Cardoso, C. S., M. J. Hötzel, D. M. Weary, J. A. Robbins, and M. A. G. von Keyserlingk. 2016a. Imagining the ideal dairy farm. J. Dairy Sci. 99:1663-1671. https://doi.org/10.3168/jds.2015-9925.

Cardoso, C. S., M. A. G. von Keyserlingk, and M. J. Hötzel. 2016b. Trading off animal welfare and production goals: Brazilian dairy farmers' perspectives on calf dehorning. Livest. Sci. 187:102-108. https://doi.org/10.1016/j.livsci.2016.02.010.

Cardoso, C. S., M. A. G. von Keyserlingk, and M. J. Hötzel. 2017. Brazilian citizens: Expectations regarding dairy cattle welfare and awareness of contentious practices. Animals (Basel) 7. https://doi .org/10.3390/ani7120089.

Clark, B., G. B. Stewart, L. A. Panzone, I. Kyriazakis, and L. J. Frewer. 2016. A systematic review of public attitudes, perceptions and behaviours towards production diseases associated with farm animal welfare. J. Agric. Environ. Ethics 29:455-478. https://doi .org/10.1007/s10806-016-9615-x.

Cornish, A., D. Raubenheimer, and P. McGreevy. 2016. What we know about the public's level of concern for farm animal welfare in food production in developed countries. Animals 6:74. https://doi .org/10.3390/ani6110074.

Dean, M., P. Lampila, R. Shepherd, A. Arvola, A. Saba, M. Vassallo, E. Claupein, M. Winkelmann, and L. Lähteenmäki. 2012. Perceived relevance and foods with health-related claims. Food Qual. Prefer. 24:129-135. https://doi.org/10.1016/j.foodqual.2011 10.006 .

Debona, D. 2014. Casos de Leite Adulterado Em SC Geram Apreensão Em Consumidores e Empresas. Accessed Jul. 27, 2017. http: //dc.clicrbs.com.br/sc/noticias/noticia/2014/11/casos-de-leite -adulterado-em-sc-geram-apreensao-em-consumidores-e-empresas $-4635283 . h t m l$.

Denzin, N. K., and Y. S. Lincoln. 2005. Handbook of Qualitative Research. 3rd ed. Sage Publications, Thousand Oaks, CA.

Dockès, A. C., and F. Kling-Eveillard. 2006. Farmers' and advisers' representations of animals and animal welfare. Livest. Sci. 103:243-249. https://doi.org/10.1016/j.livsci.2006.05.012.

Driessen, C. 2012. Farmers engaged in deliberative practices; An ethnographic exploration of the mosaic of concerns in livestock agriculture. J. Agric. Environ. Ethics 25:163-179. https://doi.org/10 $.1007 / \mathrm{s} 10806-010-9293-\mathrm{z}$.

Ellis, K. A., K. Billington, B. McNeil, and D. E. F. McKeegan. 2009 Public opinion on UK milk marketing and dairy cow welfare. Anim. Welf. 18:267-282.

Eurobarometer. 2007. European cultural values. European Commission, Brussels, Belgium.

Folha, O. 2007. Leite Adulterado Era Vendido Para Parmalat e Calu, Diz PF. Accessed July 27, 2017. http://www1.folha.uol.com.br/ cotidiano/2007/10/338822-leite-adulterado-era-vendido-para -parmalat-e-calu-diz-pf.shtml.

Fraser, D. 2008. Animal welfare and the intensification of animal production. Pages 167-189 in The Ethics of Intensification: Agricultural Development and Cultural Change. P. B. Thompson, ed. Springer Netherlands, Dordrecht, the Netherlands.

Fraser, D., D. M. Weary, E. A. Pajor, and B. N. Milligan. 1997. A scientific conception of animal welfare that reflects ethical concerns. Anim. Welf. 6:187-205.

Guest, G., K. M. MacQueen, and E. E. Namey. 2012. Applied Thematic Analysis. SAGE Publications Inc., Thousand Oaks, CA.

Guivant, J. S., and P. Macnaghten. 2015. An analysis of the GM crop debate in Brazil. Pages 74-104 in Governing Agricultural Sustainability: Global Lessons from GM Crops. P. Macnaghten and C.R. Susana, ed. Routledge, London, UK.

Hötzel, M. J. 2016. Letter to the editor: Engaging (but not "educating") the public in technology developments may contribute to a socially sustainable dairy industry. J. Dairy Sci. 99:6853-6854.

Hötzel, M. J., C. S. Cardoso, A. Roslindo, and M. A. von Keyserlingk. 2017. Citizens' views on the practices of zero-grazing and cow-calf separation in the dairy industry: Does providing information in- crease acceptability? J. Dairy Sci. 100:4150-4160. https://doi.org/ 10.3168/jds.2016-11933.

Hötzel, M. J., and J. N. Sneddon. 2013. The role of extensionists in Santa Catarina, Brazil, in the adoption and rejection of providing pain relief to calves for dehorning. J. Dairy Sci. 96:1535-1548. https://doi.org/10.3168/jds.2012-5780.

IBGE. 2009. Censo Agropecuário 2006. Instituto Brasileiro de Geografia e Estatística (IBGE). Accessed Aug. 3, 2016. http://biblioteca .ibge.gov.br/visualizacao/periodicos/51/agro_2006.pdf.

IBGE. 2012. Censo Demográfico 2010. Accessed Oct. 9, 2017. https:// ww2.ibge.gov.br/home/estatistica/populacao/censo2010/.

Lassen, J., P. Sandøe, and B. Forkman. 2006. Happy pigs are dirty! Conflicting perspectives on animal welfare. Livest. Sci. 103:221230. https://doi.org/10.1016/j.livsci.2006.05.008.

Lehmen, F. 2017. Quadrilha Usava Soda Cáustica e Outras Substâncias Para Adulterar Leite. Accessed Jul. 27, 2017. http://g1.globo .com/hora1/noticia/2017/03/quadrilha-usava-soda-caustica-e -outras-substancias-para-adulterar-leite.html.

Magalhães, R. S. 2009. A "masculinização" da produção de leite. Rev. Econ. Sociol. Rural 47:275-299.

Magouras, I., L. P. Carmo, K. D. C. Stärk, and G. Schüpbach-Regula. 2017. Antimicrobial usage and resistance in livestock: Where should we focus? Front. Vet. Sci. 4:148. https://doi.org/10.3389/ fvets.2017.00148

MDA. 2015. Conferências Territoriais de Juventude. Accessed Aug. 3, 2016. http://www.mda.gov.br/sitemda/sites/sitemda/files/user _arquivos_3/ps02.pdf.

Meijboom, F. L. B. 2017. More than just a vet? Professional integrity as an answer to the ethical challenges facing veterinarians in animal food production. Food Ethics 1:209-220. https://doi.org/10 $.1007 / \mathrm{s} 41055-017-0019-\mathrm{z}$.

Miele, M., I. Veissier, A. Evans, and R. Botreau. 2011. Animal welfare: Establishing a dialogue between science and society. Anim. Welf 20:19.

Miles, M. B., and A. M. Huberman. 1994. Qualitative Data Analysis: An Expanded Sourcebook. 2nd ed. Sage Publications Inc., Thousand Oaks, CA.

O'Brien, M. C., A. McConnon, L. E. Hollywood, G. J. Cuskelly, J. Barnett, M. Raats, and M. Dean. 2015. Let's talk about health: shoppers' discourse regarding health while food shopping. Public Health Nutr. 18:1001-1010. https://doi.org/10.1017/ S1368980014001116.

Oliveira, C. J. B., W. D. Lopes Júnior, R. C. R. E. Queiroga, P. E. N Givisiez, P. S. Azevedo, W. E. Pereira, and W. A. Gebreyes. 2011. Risk factors associated with selected indicators of milk quality in semiarid northeastern Brazil. J. Dairy Sci. 94:3166-3175. https:// doi.org/10.3168/jds.2010-3471.

Pieper, L., M. G. Doherr, and W. Heuwieser. 2016. Consumers' attitudes about milk quality and fertilization methods in dairy cows in Germany. J. Dairy Sci. 99:3162-3170. https://doi.org/10.3168/ jds.2015-10169.

Prickett, R. W., F. B. Norwood, and J. L. Lusk. 2010. Consumer preferences for farm animal welfare: results from a telephone survey of US households. Anim. Welf. 19:335-347.

Robson, C., and K. McCartan. 2016. Real World Research: A Resource for Social Scientists and Practitioner-Researchers. 4th ed. Printer Trento, Italy

Rucinque, D. S., A. P. O. Souza, and C. F. M. Molento. 2017. Perception of fish sentience, welfare and humane slaughter by highly educated citizens of Bogotá, Colombia and Curitiba, Brazil. PLoS One 12:e0168197. https://doi.org/10.1371/journal.pone.0168197.

Spanevello, R. M. 2008. The succession dynamics in family farming. Federal University of Rio Grande do Sul, Porto Alegre, Brazil.

Steinfeld, H. 2006. Livestock's long shadow: Environmental issues and options. Food and Agriculture Organization of the United Nations, Rome, Italy.

Stropasolas, V. L. 2011. Os desafios da sucessão geracional na agricultura familiar. Rev. Agric. (Piracicaba) 8:3

Sumner, C. L., and M. A. G. von Keyserlingk., andWeary, D. M. 2018. Perspectives of farmers and veterinarians concerning dairy cattle welfare. Anim. Front. 8:8-13. 
Te Velde, H., N. Aarts, and C. Van Woerkum. 2002. Dealing with ambivalence: Farmers' and consumers' perceptions of animal welfare in livestock breeding. J. Agric. Environ. Ethics 15:203-219. https: //doi.org/10.1023/A:1015012403331.

Thompson, P. B. 2012. Agriculture, food and society-Philosophy to nanotechnology. Adv. Dairy Technol. 24:13.

van Asselt, M., P. M. Poortvliet, E. D. Ekkel, B. Kemp, and E. N. Stassen. 2018. Risk perceptions of public health and food safety hazards in poultry husbandry by citizens, poultry farmers and poultry veterinarians. Poult. Sci. 97:607-619. https://doi.org/10 $.3382 / \mathrm{ps} / \mathrm{pex} 325$.

Van Calker, K. J., P. B. M. Berentsen, G. W. J. Giesen, and R. B. M. Huirne. 2005. Identifying and ranking attributes that determine sustainability in Dutch dairy farming. Agric. Human Values 22:53-63. https://doi.org/10.1007/s10460-004-7230-3.

Vanhonacker, F., W. Verbeke, E. Van Poucke, and F. A. M. Tuyttens. 2008. Do citizens and farmers interpret the concept of farm animal welfare differently? Livest. Sci. 116:126-136. https://doi.org/10 $.1016 /$ j.livsci.2007.09.017.

Vargas-Bello-Pérez, E., G. C. Miranda-de la Lama, D. L. Teixeira, D. Enríquez-Hidalgo, T. Tadich, and J. Lensink. 2017. Farm ani- mal welfare influences on markets and consumer attitudes in Latin America: The cases of Mexico, Chile and Brazil. J. Agric. Environ. Ethics. https://doi.org/10.1007/s10806-017-9695-2.

von Keyserlingk, M. A. G., and M. J. Hötzel. 2015. The ticking clock: Addressing farm animal welfare in emerging countries. J. Agric. Environ. Ethics 28:179-195. https://doi.org/10.1007/s10806-014 -9518-7.

Wikman, I., A. H. Hokkanen, M. Pastell, T. Kauppinen, A. Valros, and L. Hänninen. 2013. Dairy producer attitudes to pain in cattle in relation to disbudding calves. J. Dairy Sci. 96:6894-6903. https: //doi.org/10.3168/jds.2012-6128.

Wolf, C. A., G. T. Tonsor, M. G. S. McKendree, D. U. Thomson, and J. C. Swanson. 2016. Public and farmer perceptions of dairy cattle welfare in the United States. J. Dairy Sci. 99:5892-5903. https:// doi.org/10.3168/jds.2015-10619.

Yunes, M. C., M. A. G. von Keyserlingk, and M. J. Hötzel. 2017. Brazilian citizens' opinions and attitudes about farm animal production systems. Animals 7:75. https://doi.org/10.3390/ani7100075. 